\title{
Evliyâ Çelebi's Strange and Wondrous Europe
}

Le monde étrange et merveilleux d'Evliyâ Çelebi

\section{Yeliz Özay}

\section{(2) OpenEdition}

\section{Journals}

\section{Electronic version}

URL: https://journals.openedition.org/ceb/3975

DOI: $10.4000 /$ ceb.3975

ISSN: 2261-4184

\section{Publisher}

INALCO

\section{Printed version}

Number of pages: 61-69

ISBN: 978-2-85831-205-4

ISSN: 0290-7402

\section{Electronic reference}

Yeliz Özay, "Evliyâ Celebi's Strange and Wondrous Europe", Cahiers balkaniques [Online], 41 | 2013,

Online since 19 May 2013, connection on 06 July 2021. URL: http://journals.openedition.org/ceb/3975 ; DOI: https://doi.org/10.4000/ceb.3975

This text was automatically generated on 6 July 2021 .

\section{(ब) $(1) \Theta$}

Cahiers balkaniques est mis à disposition selon les termes de la Licence Creative Commons Attribution - Pas d'Utilisation Commerciale 4.0 International. 


\title{
Evliyâ Çelebi's Strange and Wondrous Europe
}

\author{
Le monde étrange et merveilleux d'Evliyâ Çelebi
}

Yeliz Özay

1 The Seyahatnâme is an extraordinary source for literary and cultural studies, not just because of its gigantic size but also because it includes a wide range of narrative styles and discourses. The volume and variety have led researchers to treat the text in segments and sub-categories. In fact, the narratives are not randomly chosen and fragmentary. They are intentionally selected, fictionalized narratives with an organic connection among themselves and forming a consistent whole. To see how Evliyâ Çelebi, as a talented storyteller, composes his work and generates a firm fictional structure, we have to trace how the polyphonic and polychromatic strands intersect and intertwine, producing new and surprising texts. While we need this kind of holistic reading to analyze formal and contextual structure, Evliyâ himself draws our attention to some narratives in particular by repeated recourse to certain narrative genres. One such genre, in which literary taste pushes the limits of imagination of both narrator and reader, is that of "marvels and wonders" (acayib ü garayib; Arabic 'ajầib wa gharầib).

\section{"Marvels and wonders"}

2 With the heading "marvels and wonders" Evliyâ prepares his readers for a different narrative world. This is important for appreciating him as a storyteller and understanding the fictional dimensions of his work. This favored category reflects the ideals and beliefs of his age. Narratives of this kind do not merely satisfy literary taste and cultural curiosity, nor are they completely independent from the larger narrative world of the Seyahatnâme. As with other kinds of narratives, to analyze them correctly we must pay attention to the context, what Evliyâ says before and after them. 
Following these references is essential for understanding Evliyâ's narrative style and the integrity of his fiction.

3 Some commentators, while accepting the Seyahatnâme as a cultural treasure and an extraordinary piece of literature, are ambivalent about the "marvels and wonders" sections, which, in their view, reflect Evliyâ's weak side and his tendency toward excess. Fahir İz, for example, argues that Müntehabat-ı Evliyâ Çelebi - the first publication of Evliyâ's work in Turkey, a book that especially collected these kinds of stories - has given the Seyahatnâme a bad name: "Even after the first eight volumes of the work had been published, many people, including some scholars, did not believe anything that Evliyâ related." $(1979,61)$ For İz as well, sometimes he goes too far and relates a lot of extraordinary events that reflect the beliefs of his age, including saints' miracles, magical feats, sorceries, prophecies, and stories of supernatural creatures. This weakness has worked against Evliyâ in that for a long time nothing that he wrote was taken seriously (61).

This view, however, also reminds one of the opposite approaches. Ahmet Hamdi Tanpinar, for example, states that he reads Evliyâ Çelebi not to criticize him, but to believe in him, and that this approach turns out to be profitable $(2001,16)$. Ultimately, though, dividing Evliyâ Çelebi into two persons - a taleteller and a scholar - is the real barrier to understanding the intellect in his work.

5 Nuran Tezcan argues that the Seyahatnâme is "a work formed in the spiral of objective information and fiction. If we take the scientific criteria used to judge the objective layer and apply them to the work as a whole, we overlook its power as fiction" (2009, 388). Indeed, evaluations based on the distinction between reality and fiction threaten to compromise the literary and cultural value of the work. Also, for the episteme of 17th century Ottoman society, we cannot argue about such a distinction between reality and fiction, or a distinction between evidence-based knowledge and wisdom, using the critical measures of our own day. As a narrator picking up his story from his social ground, Evliyâ does not distinguish history, mythology, legend and rumor; so fitting his narratives into sharply defined categories of "reality" and "fiction" is unproductive.

Robert Dankoff suggests that the Seyahatnâme is "a huge example on the literary level of [an] Ottoman mentality [that] oscillates between a down-to-earth realism and a love for 'marvels and wonders"' $(2004,214)$. This way of looking at the issue is useful in determining both the mentality of the period and the function of the wondrous narrations in the text. Dankoff also points out:

The Seyahatnâme is by no means simply a straightforward travel narrative. Rather, the roughly chronological travel account merely provides the armature within which the author does many other things. These other things ... make up the bulk of the work, and so cannot be considered simply as digressions to the travel account. $(2005,72)$

7 Narratives of "marvels and wonders," while they seem to be digressions, have a longstanding history and an indispensable function in the tradition of travel narratives. "Beginning in the ninth century, the 'Ajâ'ib - marvelous tales - made up an entire sector of knowledge and participated in both edifying literature and literature for entertainment" (Touati 2010, 227). Despite this long history, debate persists as to what genre they belong to, what layer of discourse they reside in, whether the information they provide is objective or subjective. 
Syrinx Von Hees, states that many researchers use the term ağa $\bar{a} i b$ literature to dismiss the scientific validity of some texts, despite their own claim to present serious information $(2005,103)$. To these scholars, it makes sense to deny the scientific value of such texts. But why should the notion of $a g \breve{a}^{\prime} i b$ be contrasted with science at all? Von Hees also points out:

The supposed characteristic of ağā'ib literature, namely that it consists of entertaining stories originating from folklore, is turned around to prove the unscientific or unscholarly character of the genre. Thus, it is claimed that medieval authors are not interested in serious scientific research, but wish only to offer popular entertainment. The question remains, of course, as to what 'science' or 'scholarship' might stand for in this discussion. (2005, 103-104)

This approach turns out to be a question in literary studies too: Are narratives of "marvels and wonders" entertaining literature or educational literature? As opposed to those who see them only as examples of literary art, Carra de Vaux has argued:

The word 'Marvel' does not represent something that does not exist or never has existed. Marvels are monuments, facts, and beings like those we encounter in geography and history. It is not sure that they are true; it is even less sure that they are false: they are above all hard to confirm (after Touati, 227-28).

10 At this point we are confronted with a twofold approach regarding narratives of "marvels and wonders" and a choice between enjoying them as entertainment literature and checking them for their truth value. However, the persistence of marvels in the world of narrative demonstrates that this genre has a special function, both for the reader or listener and for the literary work in which it is found. Thus, rather than assuming "our own opposition between 'historical' and 'artistic' truth" (Eagleton 1996, 1 ), we need to focus on the practical and textual functions of these narratives.

11 Touati emphasizes that while 'Ajâ'ib are frequently found in medieval literature, entertainment is not their sole function:

In geography, for example, they operated within the categories of the admirable and the believable. The admirable was what is worthy of holding attention and being fixed in writing in a book that, in turn, was itself judged worthy of being read or learned by heart.... As the 'Ajâ'ib merged with the medieval travel narrative, the categories of the admirable took on added force and authority.... For the Greeks, a travel narrative could not claim to be a faithful account without including material that comes under the heading of thôma [wonders]. The same might be said of Muslims of the Middle Ages, who considered that such a work had missed its target if it did not include some 'Ajâ'ib, particularly since all medieval travel narratives were programmed to end with something extraordinary. This constraint was both cultural and narrative. At times it seems the only justification for reading or listening to a travel narrative. (229-30)

12 Thus Evliyâ's use of this category cannot be considered an accidental or individual choice, but seems to be a conscious decision based on the Islamic tradition of travel writing.

13 To fully understand what Evliyâ finds to be "strange and wondrous" and why he does so, and at what points he warns readers or listeners that they are facing a narrative of "marvels and wonders," we may classify such narratives under certain concepts, such as talisman and spells, magic and witchcraft, dreams and prophecies, adventures, physical appearances, animals, different beliefs or cultures, landforms, architectural structures, etc. These include most of the basic concepts in Evliyâ's travels, indeed in his life. Thus it is difficult to say that narratives of "marvels and wonders" in the 
Seyahatnâme focus on certain restricted topics. That is to say, it is possible for Evliyâ to see a strange ritual in one church that he has not seen in other churches; or while one cave is ordinary, another can be full of mysteries. This suggests that the process of travel is important in the formation of such stories.

\section{The importance of the cultural context}

14 So far, the importance of narratives of "marvels and wonders" in travel literature has been stressed. Here, we should point out what Evliyâ finds worth recounting as "strange and wondrous" about Europe in light of these arguments. However, before doing this, we have to define where Europe is for Evliyâ Çelebi. To avoid anachronistic judgments, first of all, we should admit that what "Europe" and "the West" imply to us about geography and civilization is very different from what they imply to Evliyâ.

Bernard Lewis states that both the terms "Europe" and "the West" are European and Western terms, and had no real meaning in any other place in the world, especially in the Middle East up until the 19th century $(2000,8)$. In his study on the Ottomans and the concept of Europe, Gilles Veinstein explains where Europe was for the Ottomans by using terms and concepts like dâr ül İslam ("the abode of Islam"), dâr ül-harb ("the abode of war"), bilâd-ül küfriye ("infidel or Christian lands") and dâr ül-sulh ("the abode of peace") $(2010,49)$. Veinstein's conclusion is that Christian Europe is a part of the dâr ül-harb or bilâd-ül küfriye (50). As Lewis points out, what we call the relationship between the Ottomans and Europe was, for the Turks, the relationship between Muslims and Christians. Accordingly, European people were generally termed kâfir or küffar, and Europe was kâfiristan. The term Frengistan, which Evliyâ Çelebi used, refers to Europe, but, as Jacques Bacqué-Grammont points out, neither Frengistan nor the "Franks" are mentioned according to their countries in the Seyahatnâme $(2010,84)$. Still, when such scholars as Cemal Kafadar, Djanirah Couto, Faruk Bilici, and Ilber Ortayl1 ${ }^{1}$ emphasize how Europe was eager to learn about the Ottoman Empire in the 17th century while Ottoman intellectuals were indifferent to Europe, they always mention Evliyâ Çelebi as an exception to this. In any case, for the 17th century Ottoman mentality, and for Evliyâ who was a part of it, the image of Europe was primarily tied to religion and to the boundaries of the empire rather than to geography and civilization.

The "strange and wondrous" narratives Evliyâ records about Kâfiristan or Frengistan consist of texts with very different themes and forms, as is true of his work as a whole. So we have to ask, "For Evliyâ, what was interesting and worth reporting about Europe under the title acayip and garayip? And what was his point of view and the effect he wanted to evoke in each text? To answer these questions, we need to ask just why and what these texts imply.

As it is mentioned before, Evliyâ rarely places a totally fictitious story under the title of acayip and garayip. And with the relevant texts about Europe, we simply do not come across any supernatural, fantastic, or untrue stories. And so, in these texts, the terms acayib and garayib refer more than anything else to the realm of reality, rather than fantasy. In Volume 7, for example, under the title of "san'at-1 garibe", he is enthusiastic in his admiration of alarm clocks, mechanical carriages and mills, effigies of Turkish captives moving like a wound clock, and other clockwork mechanisms (VII.57b-59a). Or, under the "Fasl-ı diğer-i kâr-ı acîb-i cerrâhân" title, he describes a patient's sickness and the practices of surgeons in great detail, using powerful metaphors (VII.63a). In both 
cases, he conveys information about these new and different technological devices and practices to his readers and shares his enthusiasm with them. Although researchers ${ }^{2}$ can still today question the credibility and technicality of what he relates, such information was clearly interesting and worth reporting about for him, and so he did not see telling such things as being opposed to science, but rather as encouraging it. In addition to objects and incidents evoking admiration or amazement, Evliyâ also uses the title acayib and garayib when telling about strange traditions. The acayip and garayip non-Muslim - Evliyâ uses the word "kâfir" - rituals he sees in Venice, as well as the extraordinary respect the king shows to women in Vienna, are literally "strange" for Evliyâ and his readers. This is why he needs to present the reasons behind these astonishing traditions. While Evliyâ remains true to his faith with regard to divine cause and effect, there are no limits when it comes to appreciating human effort and creativity.

Apart from these records, we also come across the narration of grotesque bodies and entertaining shows under the title of acayip and garayip in Evliyâ's account of Europe. For example, at one point, Evliyâ describes the king of Vienna, who is ugly and has a strange face. The description, which uses metaphors similar to those Evliyâ uses to describe grotesque bodies elsewhere in the Seyahatnâme, is highly exaggerated, and aims to disturb the reader by provoking the feeling of disgust. We might say that, with this and similar descriptions, Evliyâ is trying to display his power as a storyteller, rather than to convey knowledge.

In another section, where Evliyâ relates the strange performances of talented "infidels", the whole show is about the performers' imitation of animals, and does not include any supernatural acts. Thus, the use of the term "acayip" here can only be because of Evliyâ's amazement at the performers' talent. Evliyâ loves such entertainments, and he places his descriptions of almost all of them under the title "acayib and garayib" in order to attract the reader's attention.

21 Now, if we attempt to, temporarily, summarize all of the information given in these particular acayip and garayip texts, disregarding how Evliyâ told about them as well as his point of view, this is what we get: in Venice, Evliyâ Çelebi observes a Christian ritual. In Vienna, he comes across certain unfamiliar devices and observes the practices of surgeons. Also in Vienna, he encounters an ugly king who openly shows respect to women.

This quick summary is not presented to show the simplicity of the texts. On the contrary, we should admit that the complex structure of the work cannot be analyzed without close reading and using a variety of different methods. Here, the aim is to question the possibility of each "strange and wondrous" (acayip and garayip) experience for a travel narration whose essence can be fit into just one sentence. What we see here is that the traveler who had the chance to experience these things directly, and the reader who did not are astonished by these accounts, not because they are born out of fantasy and found only in untrue stories, but, on the contrary, because they do exist in reality.

The only text where it is obvious that Evliyâ is interested in dramatic narration is in a section called "The Strange Spectacle of Küheylan". This is an adventure story about a horse sent by the Ottoman sultan as a gift to the king in Vienna. However, the story does not simply state that the horse was a gift to the king, but also has a narrative added to it. This new story is interrelated to another story about a Circassian soldier 
and his horse, a story that is still circulated in oral culture in various versions. The story keeps the tension of the opposition between the kâfir and the gazi, and the narrator is included in the story as a character. All of these elements make the new story more plausible for the reader. However, the story is doing much more than just trying to relate a true story. Above all, Evliyâ is a storyteller here, one consciously using narration as a tool to tell a good story full of mystery in order to satisfy his and his readers' literary taste. The modern reader might question how much of this story is based in reality and how much came from the author's imagination. But in any case, we have to admit that this is not a story born purely out of fantasy. After all, Evliyâ presents his readers with a real animal, a horse, and not some marvelous beast. The dramatic actions and the dramatic end of the story present very realistic points of view and messages, in terms of the story's own context. In the end, though, rather than asking unanswerable questions about the reality of the text, even if it is a dramatic story, it would be better to simply remain within the work's own boundaries, as, thus, we can make deeper analyses in line with the story's context, and thus get closer to the world of meanings in the work, both in terms of this story and in terms of the Seyahatnâme as a whole.

In conclusion, in order to avoid anachronistic judgments, we have to do a critical analysis without ignoring either the $17^{\text {th }}$ century Ottoman systems of knowledge or the texts that give expression to them. Without considering the Seyahatnâme within its cultural context, we cannot really establish, in the text, the difference between the natural and the supernatural, between truth and untruth, between reality and fantasy. And, when it comes to "acayib and garayib", it is in fact not even necessary to mark any boundaries separating the real from the imaginative in order to be able to take these texts seriously. Considering the diversity of the themes and forms grouped under this title, each individual narration needs to be analyzed in a different way depending on its own context. This kind of reading has been tried here in looking at Evliyâ's "acayip and garayip" texts relating to Europe, which actually give the lie to the idea that such texts deal only with the supernatural and the marvelous, or that, to a 17th century reader, they were unscholarly texts that failed to reflect reality. The fact is, they deal with all sorts of things besides what we might call the supernatural and marvelous, and, partly because of this, they were not seen as "unscholarly" or "inaccurate" at all.

\section{BIBLIOGRAPHY}

Bacqué-Grammont, Jean-Louis, (2010), “Evliyâ Çelebi'nin Seyahatnâmesi'nde Portekiz ve Portekizliler". Harp ve Sulh: Avrupa ve Osmanllar. İstanbul: Kitap Yayınevi, pp.83-95.

Couto, Dejanirah, (2010), “Giriş”. Harp ve Sulh: Avrupa ve Osmanllar. İstanbu: Kitap Yayınevi, pp. 13-47.

Dankoff, Robert, (2004), An Ottoman Mentality: The World of Evliyâ Çelebi. Leiden: Brill. 
Dankoff, Robert, (2005), “The Seyahatnâme of Evliyâ Çelebi as a Literary Monument.” Journal of Turkish Literature 2, 71-83.

Dankoff, Robert, (2003), Evliyâ Çelebi. Evliyâ Çelebi Seyahatnâmesi 7. Kitap - Topkapı Sarayı Bağdat 308 Yazmasının Transkripsiyonu - Dizini. Yay. Haz. Robert Dankoff, Seyit Ali Kahraman ve Yücel Dağll. İstanbul: Yapı Kredi Yayınları.

Eagleton,Terry, (1996), Literary Theory: An Introduction. 2nd ed. Oxford: Blackwell Publishers Ltd.

İz, Fahir, (1979), “Evliyâ Çelebi ve Seyahatnâmesi”. Boğaziçi Üniversitesi Dergisi, Beşeri Bilimler 7, 6179. [Reprint: Belleten 53 (1989), 709-33].

Lewis, Bernard, (2000), Ortadoğu'nun Çoklu Kimliği. Çev. Mehmet Harmancı. İstanbul: Sabah Kitaplar1.

Tanpınar, Ahmet Hamdi, (2001), Beş şehir. İstanbul: Yapı Kredi Yayınları.

Tezcan, Nuran, (2009), “17. Yüzyıl Osmanlı Türk Edebiyatı ve Seyahatnâme”. Çağının Sıradışı Yazarı: Evliyâ Çelebi. Haz. Nuran Tezcan. İstanbul: Yapı Kredi Yayınları.

Touati, Houari, (2010), Islam and Travel in the Middle Ages. Tr. Lydia G. Cochrane. Chicago and London: The University of Chicago Press.

Veinstein, Gilles, (2010), “Osmanlılar ve Avrupa Kavramı”. Harp ve Sulh: Avrupa ve Osmanllar. İstanbul: Kitap Yayınevi, 47-57.

Von Hees, Syrinx, (2005), “The Astonishing: a critique and re-reading of A ‘̆ă’'ib literature”. Middle Eastern Literatures. Vol. 8. No. 2 (July 2005): 101-121.

\section{NOTES}

1. See: Cemal Kafadar. Kim Var imiş Biz Burada Yoğ iken: Dört Osmanll: Yeniçeri, Tüccar, Derviş ve Hatun; İlber Ortayl. Avrupa ve Biz; Dejanirah Couto. "Giriş", Harp ve Sulh: Avrupa ve Osmanllar; Faruk Bilici. "XVII. Louis Döneminde Fransa ile Türkiye Arasındaki Kültürel İlişkiler”, Harp ve Sulh: Avrupa ve Osmanlilar.

2. In his study about the surgical operations Evliya observed in Vienna, Zafer Önler states that medical studies in Europe in the 17th century had more sophisticated methods than Ottoman medicine. "Evliyâ Çelebi'nin Viyana'dan Aktardığı Cerrahiye İlişkin Üç Gözlem”. Çağııın Sıradışı Yazarı: Evliyâ Çelebi. Haz. Nuran Tezcan. İstanbul: Yapı Kredi Yayınları, 2009. 293-305.

\section{ABSTRACTS}

The Seyahatnâme is an extraordinary source for literary and cultural studies, not just because of its size but also because it includes a wide range of narrative styles and discourses. Evliyâ himself draws our attention to some narratives in particular; one such genre, in which literary taste pushes the limits of imagination of both narrator and reader, is that of marvels and wonders. These parts while they seem to be digressions, have a long-standing history and a function in the tradition of travel narratives. In fact, without considering the Seyahatnâme within its cultural 
context, we cannot establish, in the text, the difference between the natural and the supernatural, truth and untruth, reality and fantasy. When it comes to marvels and wonders, it is not necessary to mark any boundaries separating the real from the imaginative in order to be able to take these texts seriously. Considering the diversity of the themes and forms grouped under this title, each individual narration needs to be analyzed in a different way depending on its own context.

Le Seyahatnâme est une source extraordinaire d'études littéraires et culturelles, non seulement en raison de sa taille, mais aussi parce qu'il inclut une large gamme de styles narratifs et de discours. Evliyâ lui-même attire notre attention sur certains d'entre eux en particulier ; l'un de ces genres dans lequel le goût littéraire repousse les limites de l'imagination de l'auteur comme $\mathrm{du}$ lecteur, est celui des merveilles et des prodiges. Ces morceaux qui semblent des digressions, ont une longue histoire et une fonction dans la tradition des récits de voyage. En fait, sans considérer le Seyahatnâme dans son contexte culturel, nous ne pouvons pas établir dans le texte la différence entre le naturel et le surnaturel, le vrai et le faux, la réalité et l'imaginaire. Et quand il s'agit de merveilles et prodiges, il n'est pas nécessaire de tracer des limites entre réalité et imaginaire pour prendre les textes au sérieux. Considérant la diversité des formes et des thèmes sous ce titre, chaque narration individuelle doit être analysée différemment dans son contexte.

\section{INDEX}

Subjects: Histoire, Histoire des mentalités

motsclestr Evliyâ Çelebi (1611-1682), Seyahatnâme, Osmanlı İmparatorluğu, Onyedinci yüzyılda, Tarih, Zihniyetlerin Tarihi, Seyahatnameler

Keywords: Evliyâ Çelebi (1611-1682), Seyahatnâme, Ottoman Empire, Seventeenth century, History of mentalities, travelogues

Mots-clés: Evliyâ Çelebi (1611-1682), Evliyâ Çelebi (1611-1682), Seyahatnâme, récit de voyage, Seyahatnâme

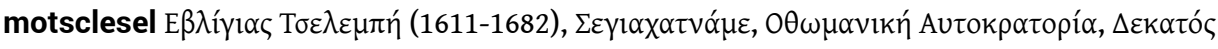

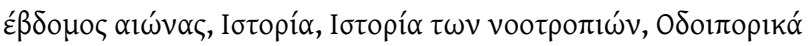

motsclesmk ЕВЛИЈА ЧЕЛЕБИЈА, (1611-1682) СЕЈАХАТНАМЕ, ОТОМАНСКАТА ИМПЕРИЈА,

СЕДУЧИАЕСЕТИОТ ВЕК, ИСТОРИЈА, ИСТОРИА НА МЕНТАЛИТЕТ, ПАТЕПИСИ

Geographical index: Empire ottoman

Chronological index: dix-septième siècle

\section{AUTHOR}

YELIZ ÖZAY

Professeur

Gazi Üniversitesi, Ankara 